\title{
PENGEMBANGAN EKONOMI DESA UTAURANO KECAMATAN TABUKAN UTARA KABUPATEN SANGIHE MELALUI USAHA KOMODITI PERTANIAN
}

\author{
Sukmarayu P. Gedoan \\ Jurusan Biologi, Fakultas Matematika dan Ilmu Pengetahuan Alam, Universitas Negeri Manado \\ sgedoan@gmail.com
}

\begin{abstract}
Abstrak
Permasalahan yang mendasar yang dirasakan oleh petani di desa Utaurano adalah kurangnya memanfaatkan lahan yang ada untuk usaha pertanian dan kurangnya informasi pengelolaan tanaman yang baik untuk dapat meningkatkan produktivitas tanaman. Selain itu, petani tidak mampu mengkombinasikan beberapa tanaman dapat ditanam pada lahan yang sama dan musim tanam yang sama. Langkah yang dilakukan untuk mengatasi masalah tersebut di atas adalah memberikan pengetahuan dalam kultur teknis tanaman pascapanen sehingga dapat dihasilkan produktivitas yang tinggi dan hasil yang berkualitas. Beberapa kegiatan yang telah dikemukakan sebelumnya yaitu : persiapan lahan, penyediaan benih yang berkualitas, pembibitan tanaman sebelum ditanam, proses seleksi tanaman sebelum ditanam, pola tanam di lahan yang telah disiapkan, pengelolaan kesuburan tanah dan tanaman, pengelolaan hama dan penyakit, dan pengelolaan pasca panen. Sosialisasi program pada kelompok tani di desa Utaurano dapat berjalan dengan baik. Peningkatan pemahaman pengelolaan tanaman dalam hal kultur teknis maupun pengendalian penyakit tanaman.
\end{abstract}

Kata Kunci: Pengembangan ekonomi, usaha komoditi pertanian, Desa Utaurano, Kecamatan Tabukan Utara.

\section{PENDAHULUAN}

Kabupaten Kepulauan Sangihe merupakan bagian utara dari provinsi Sulawesi Utara yang merupakan daerah pemekaran dari kabupaten Kepulauan Sangihe Talaud tahun 2002. Kabupaten Kepulauan Sangihe memiliki luas mencapai $11.863,58 \mathrm{~km} 2$ terdiri dari lautan $11.126,61$ km2 dan daratan 736,97 km2 (Anonim 2015). Ibukota berkedudukan di Tahuna secara keseluruhan jumlah pulau yang ada di kepulauan ini berjumlah 105 pulau dengan rincian: 79 pulau yang tidak berpenghuni dan 26 pulau berpenghuni.

Secara geografis wilayah Kabupaten Kepulauan Sangihe terletak antara $2^{\circ} 4^{\prime} 13^{\prime \prime}$ - $4^{\circ} 44^{\prime} 22^{\prime \prime} \mathrm{LU}$ dan $125^{\circ} 9^{\prime} 28^{\prime \prime}-125^{\circ} 56^{\prime}$
57" BT. Posisi kabupaten Sangihe yaitu sebelah utara dengan negara Filipina, sebelah timur dengan kabupaten Kepulauan Talaud dan laut Maluku, sebelah selatan dengan kabupaten Siau, Tagulandang, dan Biaro, dan sebelah barat berbatasan dengan laut Sulawesi (Anonim 2015). Dilihat dari klaster pembangunan kabupaten ini membagi menjadi lima klaster yaitu klaster pulau Tatoareng, klaster Dagho dsk, klaster Tahuna dsk, klaster Manalu dsk, dan klaster pulau Marore. Klaster ini sangat menentukan arah pengembangan pembangunan (Anonim 2015).

Kabupaten ini memiliki 15 kecamatan, 22 kelurahan: 22, dan 145 desa yang secara ekonomi masih sulit terjangkau oleh 
pusat pertumbuhan ekonomi, sehingga secara fisik terisolir sehingga dapat digolongkan sebagai daerah terpencil dengan aksesibilitas sarana dan prasarana yang belum memadai. Salah satu desa yang terletak di kabupaten kepulauan Sangihe adalah desa Utaurano yang terletak di kecamatan Tabukan Utara. Desa ini terletak jauh dari Tahuna sebagai ibu kota kabuputen sehingga menjadikan desa Utaurano secara ekonomi berjalan lambat. Masyarakat desa Utaurano memiliki beberapa mata pencaharian yaitu petani, nelayan, tukang bangunan, dan PNS. Umumnya penduduk desa ini sebagai petani tanaman tahunan berupa kelapa dan cengkeh, tanaman buahbuahan berupa langsat, tanaman pangan berupa singkong, talas, dan ubi jalar, sedangkan tanaman sayur-sayuran berupa kangkung, bayam, tomat, dan cabe.

Permasalahan yang mendasar yang dirasakan oleh petani di desa Utaurano adalah kurangnya memanfaatkan lahan yang ada untuk usaha pertanian dan kurangnya informasi pengelolaan tanaman yang baik untuk dapat meningkatkan produktivitas tanaman. Selain itu, petani tidak mampu mengkombinasikan beberapa tanaman dapat ditanam pada lahan yang sama dan musim tanam yang sama.

Penduduk desa Utaurano sering kali mengalami masalah dalam memenuhi kebutuhan hidup khususnya kebutuhan akan pangan. Padahal hal ini tidak perlu terjadi jika mereka mempunyai kemampuan untuk mengelola lahan yang secara fisik 166 dapat digolongkan mempunyai tingkat kesuburan yang sedang.

Berdasarkan hasil identifikasi permasalahan yang dihadapi oleh masyarakat nelayan khususnya oleh kelompok tani desa Utaurano disepakati bersama untuk diatasi melalui kegiatan pengabdian kepada masyarakat adalah sebagai berikut:

1. Kelompok tani tidak mempunyai pengetahuan yang memadai tentang kultur teknis tanaman budidaya. Petani melakukan penanaman tanaman budidaya dengan cara mereka sendiri yaitu tanpa pola tanam yang jelas. Pola tanam yang tidak jelas menyangkut tanpa jarak tanam yang teratur sehingga tanam berada dalam kondisi ketidakaturan. Pengelolaan kesuburan tanah dan tanaman yang menyebabkan tanaman tidak menghasilkan produksi sesuai dengan potensi produksi; dan

2. Kurangnya motivasi dalam meningkatkan ekonomi rumah tangga melalui usaha budidaya tanaman. Kelompok tani dalam budidaya tanaman tidak mempunyai tujuan untuk mendatangkan keuntungan.

Solusi yang ditawarkan yaitu melakukan pendampingan bagi kelompok tani dalam bimbingan kultur teknis tanaman. Pembimbingan diawali dengan persiapan lahan, penyediaan benih yang berkualitas, pembibitan tanaman sebelum ditanam, proses seleksi tanaman sebelum ditanam, pola tanam di lahan yang telah 
disiapkan, pengelolaan kesuburan tanah dan tanaman, pengelolaan hama dan penyakit, dan pengelolaan pasca panen. Selain itu kelompok tani diberi pengetahuan untuk memprediksi keadaan pasar sehingga harga jual komoditi yang ditanam akan sangat menguntungkan.

\section{METODE PELAKSANAAN}

\section{Kerangka Pemecahan Masalah}

Tingkat keberhasilan program sangat ditentukan juga oleh tingkat partisipasi dan difusi atau dapat diterima dan dirasakan manfaat kegiatan tersebut oleh khalayak sasaran yang lebih luas. Oleh karena itu dalam pelaksanaan kegiatan ini direncanakan di samping warga belajar yang tergabung dalam kelompok tani. Kegiatan ini diharapkan akan memberikan dampak yang lebih luas terutama dalam mengatasi permasalahan yang dihadapi petani saat ini. Di samping itu akan dilibatkan juga tokoh masyarakat seperti kepala desa karena dianggap memiliki pengaruh kuat dan menjadi panutan dalam pelaksanaan kegiatan tersebut. Keberlan-jutan suatu sistem usaha tani tergantung pada fleksibilitasnya dalam keadaan ling-kungan yang terus berubah (Reijntjes et al. 1999).

Konkritnya telah disepakati pula bahwa langkah yang akan dilakukan untuk mengatasi masalah tersebut di atas adalah memberikan pengetahuan dalam kultur teknis tanaman pascapanen sehingga dapat dihasilkan produktivitas yang tinggi dan hasil yang berkualitas. Secara spesifik pro- gram ini mencakup kegiatan beberapa kegiatan yang telah dikemukakan sebelumnya yaitu: persiapan lahan, penyediaan benih yang berkualitas, pembibitan tanaman sebelum ditanam, proses seleksi tanaman sebelum ditanam, pola tanam di lahan yang telah disiapkan, pengelolaan kesuburan tanah dan tanaman, pengelolaan hama dan penyakit, dan pengelolaan pasca panen.

\section{Sosialisasi Program}

Sosialisasi merupakan salah satu tahapan penting dalam mengenalkan teknologi yang akan diterapkan pada kelompok usaha. Kegiatan tersebut menyangkut transformasi gambaran ilmu pengetahuan dan teknologi dalam upaya memecahkan masalah yang dihadapi oleh nelayan. Dalam kegiatan sosialisasi ini akan dijelaskan tentang teknologi yang akan disosialisasi yaitu penganekaragaman tanaman yang akan ditanam dalam suatu lahan dengan memanfaatkan seintensif mungkin ruang yang terdapat dalam lahan tersebut. Di sini juga akan dijelaskan pentingnya pengelo-laan lahan dengan menggunakan beberapa tanaman.

Satu hal yang sering terabaikan dalam setiap implementasi program adalah bagaimana memberi pemahaman tentang rasa memiliki kegiatan tersebut. Rasa memiliki dapat ditanamkan antara lain melalui pendekatan partisipatif, di mana masyarakat atau anggota kelompok dapat memberi diri sepenuhnya untuk berpartisipasi secara aktif melalui kegiatan bekerja bersama atau aktif dalam proses implemen- 
tasi kegiatan. Hal tersebut sangat diperlukan mengingat faktor tersebut memberi andil besar terhadap kegagalan berbagai program. Setelah sosialisasi, akan ditindaklanjuti dengan kegiatan proses belajar mengajar dan kegiatan praktek atau implementasi ilmu pengetahuan dan teknologi terhadap warga belajar dan ditindaklanjuti kegiatan proses produksi oleh warga belajar yang dituntun langsung oleh tim pelaksana pengabdian kepada masyarakat.

\section{Pembuatan Unit Usaha Pertanian}

Dalam kegiatan ini akan dibuat unit usaha pertanian dari beberapa komoditi. Sebagai wujud dari kebersamaan dan rasa memiliki kegiatan ini serta sebagai wujud dari partisipasi aktif mitra dalam kegiatan pengabdian kepada masyarakat maka dalam tahapan ini seluruh anggota kelompok akan berpartisipasi secara aktif melakukan pekerjaan mulai dari pembuatan bedengan tanaman dan pembibitan tanaman. Benih cabe, tomat, terong, dan bayam dikecambahkan dulu untuk menyeleksi tanaman yang seragam dan berkualitas. Tanaman kangkung darat langsung ditanam pada bedengan yang telah disiapkan dengan jarak tanam $20 \mathrm{~cm}$ X $20 \mathrm{~cm}$. Bedengan untuk tanaman cabe dan tomat dibuat dengan ukuran lebar $90 \mathrm{~cm}$ dan panjang 15 meter (Prayudi et al. 2010).

\section{Proses Kegiatan Pembelajaran}

Proses pembelajaran yang dimaksud di sini adalah pemberian materi secara 168 teoritis dan tuntunan praktek atau pedoman kerja yang dirangkum dalam suatu buku pedoman kegiatan untuk program pembelajaran dalam rangka memberi kemampuan dan kecakapan terutama keterampilan yang mencakup (1) pengecambahan benih tanaman, (2) pembuatan bedengan, (3) pemasangan mulsa, (4) pemupukan tanaman. Aspek lain dalam program pembelajaran adalah menyangkut pemberian pengetahuan dan pembinaan mental kewirausahaan Untuk pencapaian tujuan secara optimal maka persentase materi secara teori dialokasikan sebesar 20 persen dan praktek (proses kerja) sebesar 80 persen.

\section{Implementasi Kegiatan}

Dalam rangka penyelesaian masalah spesifik usaha mitra yang mencakup beberapa kegiatan yaitu melakukan penanaman beberapa komoditi pada lahan yang telah disiapkan sebelumnya, maka nantinya tim pelaksana pengabdian kepada masyarakat akan melakukan akivitas secara bersama-sama dengan mitra kelompok. Dalam kegiatan ini tim pelaksana pengabdian kepada masyarakat bersama dengan anggota mitra terjun langsung dalam berbagai aktivitas budidaya tanaman. Dalam tahapan ini, warga belajar dituntun dalam proses:

1. Benih direndam dalam air selama kurang lebih tiga jam agak terjadi penyerapan air yang cukup. Sementara itu persiapan tempat perkecambahan 
benih sudah dilakukan sebelum benih direndam. Semua benih yang telah direndam kemudian dimasukkan dalam kotak perkecambahan dan ditunggu sampai tanaman sudah berumur tiga minggu untuk siap dipindahkan ke lapangan.

2. Pada bagian ini warga belajar dituntun juga untuk mengolah lahan sesuai dengan syarat tumbuh tanaman. Warga belajar di samping diberi pemahaman pentingnya pengelolaan bibit, pengelohan tanah, pola tanam, penanganan hama dan penyakit, dan penanganan pasca panen.

\section{Pemantapan Program Kerja dan Evaluasi}

Untuk memantau kemajuan proram kerja, dilakukan dengan cara mengevaluasi secara langsung aktivitas kerja setiap anggota kelompok tani sampai pada pelaksanaan program. Aspek yang dievaluasi mencakup respons, tindakan nyata mela-lui perilaku kerja setiap anggota kelompok tani melalui penguasaan tahap-tahap kegiatan.

\section{HASIL DAN PEMBAHASAN}

Kegiatan pengabdian kepada masyarakat yang dilaksanakan di desa Utaurano meliputi sosialisasi atau penjelasan program yang dikerjakan oleh kelompok tani. Program yang dilakukan dimulai dengan pembibitan, persiapan lahan, penanaman, pemeliharaan tanaman, dan pengendalian hama dan penyakit tanaman.

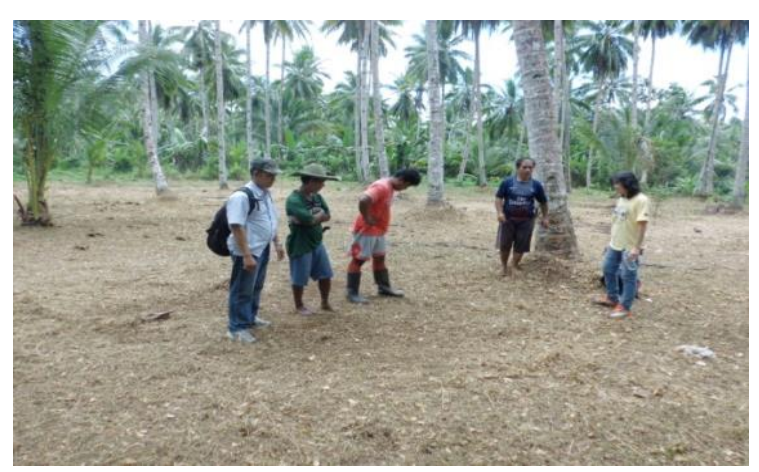

Gambar 1 Sosialisasi program

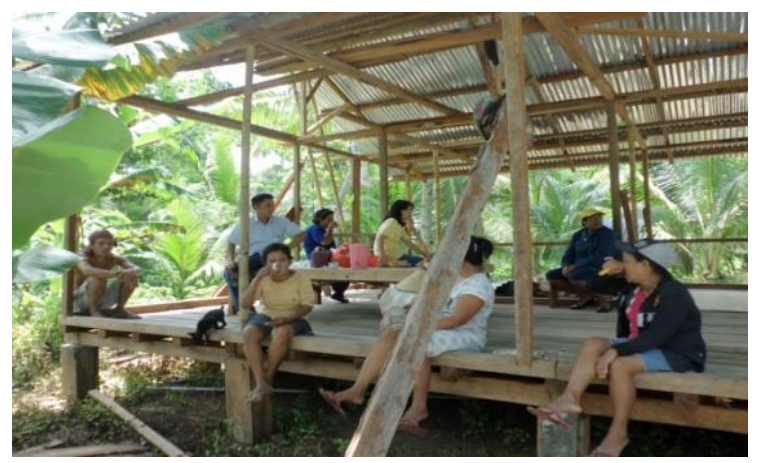

Gambar 2 Diskusi program yang akan dilaksanakan

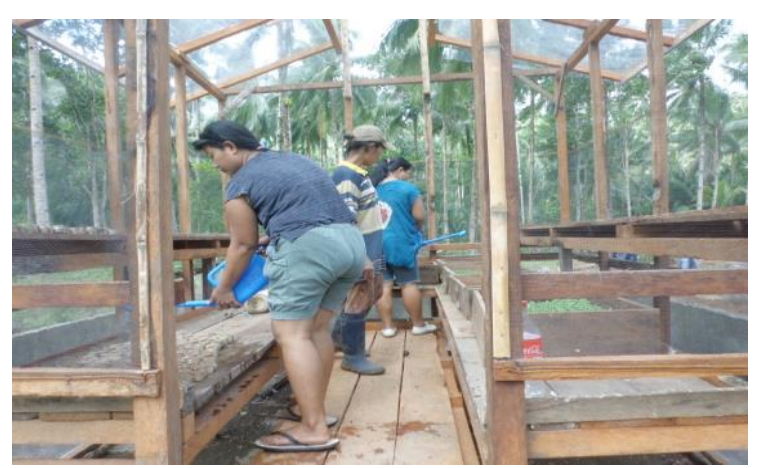

Gambar 3 Pembibitan tanaman

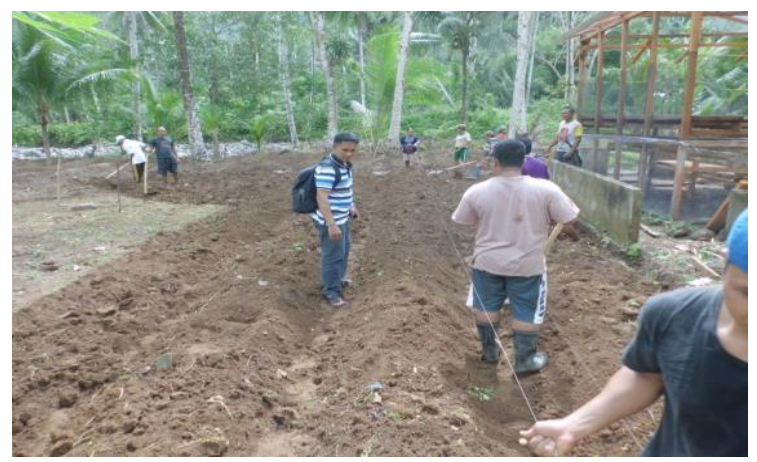

Gambar 4 Pembuatan bedengan 


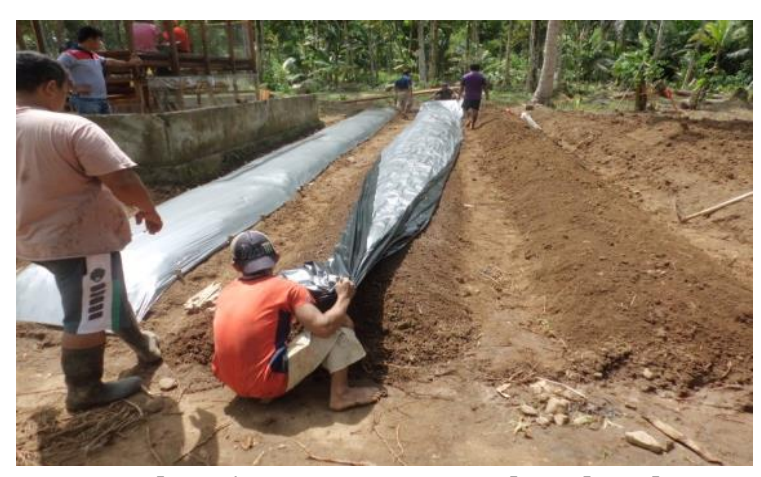

Gambar 5 Pemasangan mulsa plastik

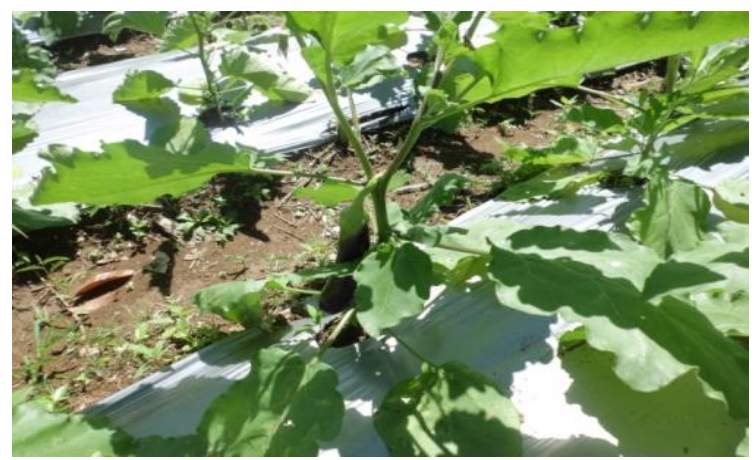

Gambar 6 Tanaman terong yang telah berproduksi

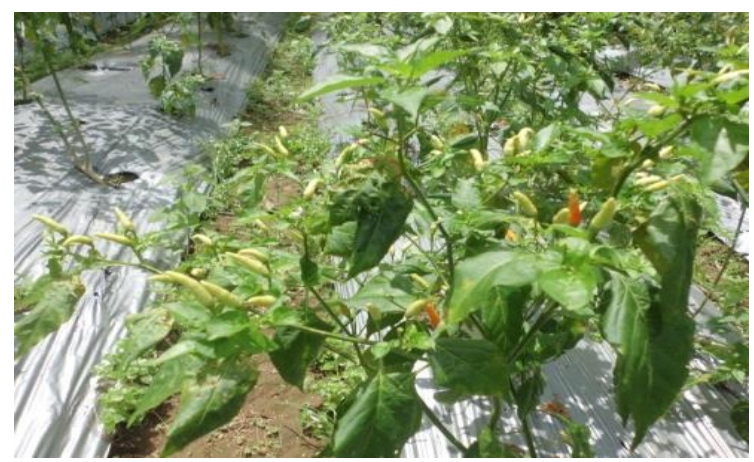

Gambar 7 Tanaman cabe yang telah menghasilkan buah

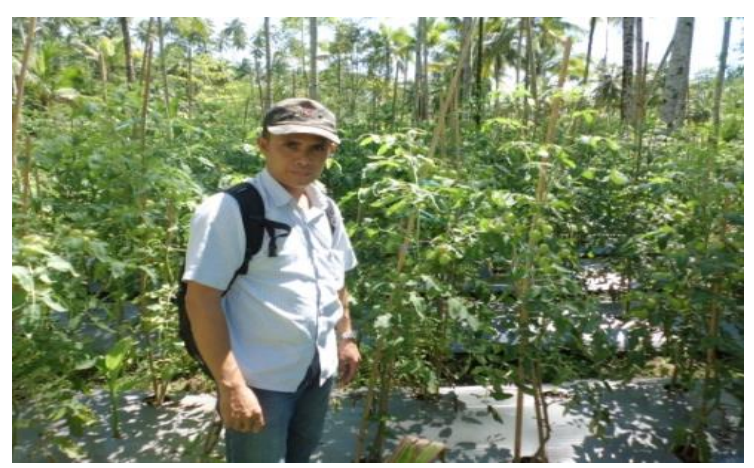

Gambar 8 Tanaman cabe yang tumbuh dengan baik dan berbuah

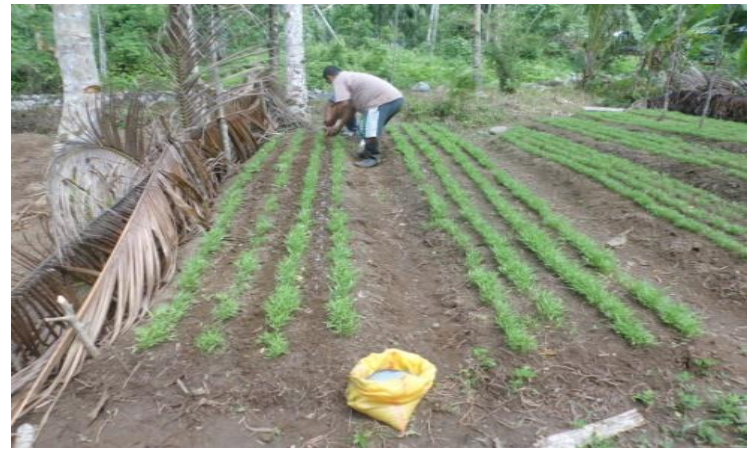

Gambar 9 Aplikasi pemupukan pada bedengan kangkung

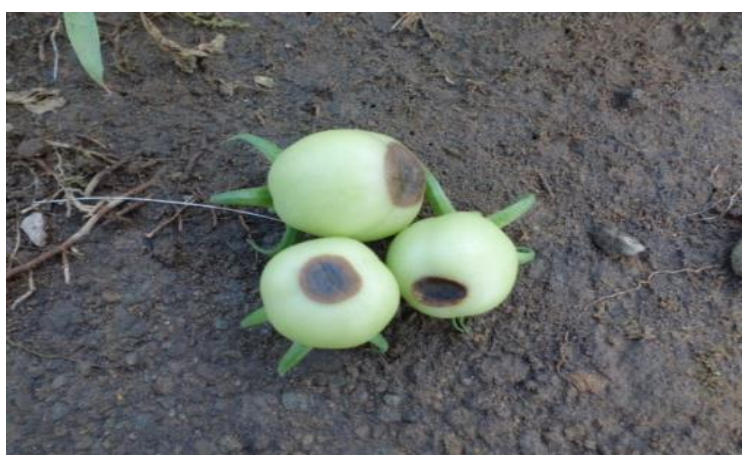

Gambar 10 Tanaman tomat yang terserang penyakit

Proses sosialisasi yang diawali dengan diskusi di lapangan maupun di pondok berjalan dengan baik (Gambar 1 dan Gambar 2). Sosialisasi dapat diterima dengan baik yang ditandai dengan kemampuan anggota kelompok tani menyerap rencana program yang akan dilaksanakan. Kelompok tani diberi masukkan tentang pentingnya kultur teknis dan diversifikasi tanaman untuk mendapat keuntungan yang diharapkan.

Tindak lanjut dari sosialisasi adalah pelaksanaan pembibitan, pembuatan bedengan, dan pemasangan mulsa plastik seperti yang disajikan pada Gambar 4, Gambar 5, dan Gambar 6. Pembibitan merupakan tahap awal budidaya tanaman cabe, tomat, dan terong. Penggunaan media tanam dan 
benih yang baik menyebabkan tingkat keberhasilan pembibitan ketiga tanaman sangat tinggi.

Pemasangan mulsa plastik sangat penting untuk meningkatkan produktivitas tanaman. Pada Gambar 6, Gambar 7, dan Gambar 8 ditunjukkan bahwa tanaman terong, cabe, dan tomat dapat berproduksi. Fungsi mulsa plastik dalam peningkatkan produktivitas tanaman yaitu dengan mempertahankan kelembaban tanah dan menghindarkan tanaman dari kompetisi dengan gulma. Cara lain untuk meningkatkan produktivitas tanaman adalah memberi nutrisi berupa aplikasi pemupukan (Gambar 9). Tanaman yang mendapat nutrisi yang cukup membuat tanaman dapat tumbuh dan berkembang dengan baik, dapat menyempurnakan daur hidupnya.

Dalam proses pertumbuhan dan perkembangan tanaman cabe, terong, dan tomat mendapat serangan penyakit, seperti ditunjukkan pada Gambar 10. Penyakit yang menyerang tanaman tomat dengan gejala seperti pada Gambar 10 disebabkan oleh jamur Alternaria solani. Penyakit ini dikenal dengan nama penyakit coklat atau penyakit kering. Cara mengendalikan penyakit ini yaitu dengan menggunakan fungisida atau secara mekanis dengan memetik dan membakar buah yang terinfeksi.

\section{KESIMPULAN DAN SARAN}

1. Sosialisasi program pada kelompok tani di desa Utaurano dapat berjalan dengan baik.
2. Peningkatan pemahaman pengelolaan tanaman dalam hal kultur teknis maupun pengendalian penyakit tanaman.

\section{KEPUSTAKAAN}

Anonim. 2015. Kabupaten Kepulauan Sangihe. http://www.kemendagri.go.id/ pages/profildaerah/kabupaten/id/71/name/sula wesi-utara/detail/7103/ kepu-lauansangihe. [7 Maret 2015].

Anonim. 2015. Selayang Pandang Sangihe. http://www.sangihekab.go.id/. [7 Maret 2015].

Prayudi B, Sutoyo, Jauhari S, Herawati H, Basuki S. 2010. Budidaya dan Pascapanen Cabe Merah (Capsicum annuum L.). Ungaran: BPTP Jawa Tengah.

Reijntjes C, Haverkort B, Waters-Bayer A. 1992. Farming For The Future, An Introduction to Low-External-Input and Sustainable Agriculture. Diterjemahkan Anonim. 1999. Pertanian Masa Depan, Pengantar untuk Pertanian Berkelanjutan dengan Input Luar Rendah. Yogyakarta: Penerbit Kanisius. 
Jurnal ABDIMAS, Vol. 9, No. 2, Desember 2016

ISSN: 1979-0953 